\title{
FAUNAL EVIDENCE OF A HOLOCENE PLUVIAL PHASE IN SOUTHERN ARABIA WITH REMARKS ON THE MORPHOLOGICAL VARIABILITY OF HELENINA ANDERSENI
}

\author{
Giordana Gennari ${ }^{1,6}$, Thomas Rosenberg ${ }^{2,3}$, Silvia Spezzaferri ${ }^{1}$, Jean-Pierre Berger ${ }^{1}$, Dominik Fleitmann ${ }^{2,3}$, \\ Frank Preusser ${ }^{2,5}$, Mahmoud Al-Shanti ${ }^{4}$ and Albert Matter ${ }^{2}$
}

\section{ABSTRACT}

Although foraminifera have been found living in inland saline lakes isolated from the sea, this phenomenon has rarely been recognized in the fossil record. This study documents the occurrence of benthic foraminifera in Holocene lake sediments located nearly $500 \mathrm{~km}$ inland from the Red Sea, in the Al-Mundafan region of southern Saudi Arabia. The lake formed during a regional pluvial period, 10,500-6000 yr BP. The presence of foraminifera and brackish charophytes in the studied section represent an interval when the lake was slightly brackish due to high evaporation. The studied sediments yielded a bispecific benthic foraminiferal fauna comprised of Helenina anderseni and Trichohyalus aguayoi, as well as the brackish charophyte genus Lamprothamnium. The benthic foraminifera are species characteristic of mangrove swamps, salt marshes, and lagoons, which are environments currently widespread along the Red Sea coasts. Because the Al Mundafan area was never connected to the sea during the Quaternary, wading birds must have been the vector that transported the foraminifera to the paleolake.

\section{INTRODUCTION}

There have been numerous reports of benthic foraminifera occurring in both Recent and ancient sediments of inland lakes, ponds, springs, and rivers (see summaries in Patterson and others, 1990; Lévy and others, 1995; Patterson and others, 1997; and Wennrich and others, 2007). Nevertheless, these are enigmatic occurrences, each of which presents an enticing challenge to research. In the present study, we document the presence of foraminifera in inland paleolake deposits of southern Arabia, and seek an explanation for this local phenomenon.

The climate of southern Arabia is strongly affected by the African-Asian monsoon. Periods of intensified monsoonal circulation during the late Pleistocene and Holocene caused significantly higher precipitation over the southern Arabian Peninsula (e.g., Fleitmann and others, 2003a). Since lacustrine sediments can provide a detailed record of paleoclimate variability, a multiproxy study of Pleistocene-Holocene lake deposits in the Empty Quarter of Saudi Arabia (Rub' al Khali) was undertaken as part of a Swiss National Science Foundation project seeking to better

\footnotetext{
${ }^{1}$ University of Fribourg, Department of Geosciences, Earth Sciences, Ch. du Musée 6, 1700 Fribourg, Switzerland

${ }^{2}$ University of Bern, Institute of Geological Sciences, Baltzerstrasse 1-3, 3012 Bern, Switzerland

${ }^{3}$ University of Bern, Oeschger Centre for Climate Change Research, Zähringerstrasse 25, 3012 Bern Switzerland

${ }^{4}$ Saudi Geological Survey, P.O. Box 54141, Jeddah 21514, Saudi Arabia

${ }^{5}$ Present address: Stockholm University, Department of Physical Geography and Quaternary Geology, 10691 Stockholm, Sweden

${ }^{6}$ Corresponding author. E-mail: giordana.gennari@unifr.ch
}

understand this pluvial period in what is still a largely unexplored region.

During fieldwork in the Al Mundafan region in March 2008, ten outcrops were sampled (Fig. 1). A total of 68 samples were taken for micropaleontological analysis and radiocarbon and OSL dating. One of these outcrops yielded two samples with foraminifera and charophytes (Fig. 2). The primary aim of our study is to reinvestigate this benthic foraminiferal fauna, first reported in the Al Mundafan area by McClure and Swain (1980), and to place it into a paleoenvironmental context.

\section{GEOLOGICAL SETTING}

The study area is located $700 \mathrm{~km}$ southeast of Mecca at the southern end of the Tuwayq sedimentary escarpment, where Holocene lakebeds are exposed within a single depression of approximately 15 square kilometers. The depression is bordered by the escarpment to the north and by dunes to the south. A modern sabkha occupies the western part of the depression.

\section{MATERIAL AND METHODS}

Sediment samples were prepared for micropaleontological quantitative analysis first by drying at room temperature. Aliquots of $\sim 40$ and $30 \mathrm{~g}$ for samples A4 and A5, respectively, were then washed through a $32-\mu \mathrm{m}$ satilon net. The two residues were left at room temperature and once dry each was sieved into 250, 125, 63, and $32 \mu \mathrm{m}$-size fractions. Each fraction was split three times and the foraminiferal content of one of those splits was quantitatively studied. Approximately 200 adult specimens were picked from the $125-250 \mu \mathrm{m}$ size-fraction and mounted on slides. Each specimen was analyzed for morphometric parameters using a KEYENCE VHX-600 digital microscope at a magnification of $200 \times$. Measurements were taken of spiral diameters (D and B) and height $(\mathrm{H})$, as well as intersutural length (ISL) of the first and penultimate chambers of the last whorl (Fig. 3) following Pearson and others, 2001. Multivariate (Principal Component Analysis) statistical treatment on morphometric data was performed with the software PRIMER 6 after data normalization (Clarke and Warwick, 2001; Clarke and Gorley, 2006). Scanning electron microscope (SEM) images were obtained at the Department of Geosciences, University of Fribourg.

The chronology of Section 8321.1 is based on radiocarbon dating, measured by accelerator mass spectrometry (AMS) at the ETH/PSI facility in Zurich (Table 1). In order to avoid age offsets due to the so-called "hard water effect", the carbonate fraction was dissolved using $5 \mathrm{M} \mathrm{HCl}$ and only phytoclasts were used for dating. The Holocene radiocarbon age was calibrated to calendar years using 


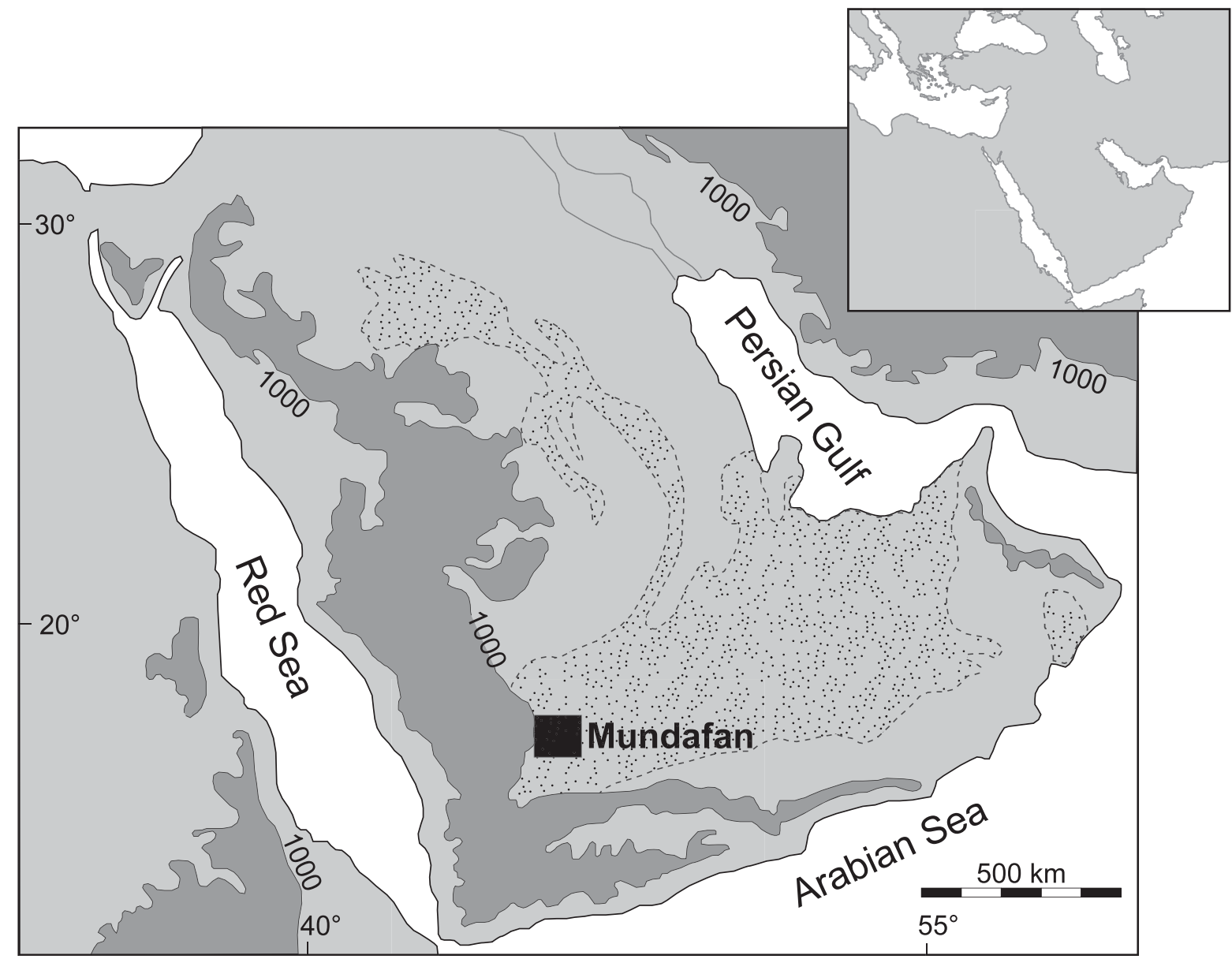

FIGURE 1. Simplified relief map of the Arabian Peninsula and surroundings showing the location of Al Mundafan. Dark grey areas are $>1000 \mathrm{~m}$ in elevation; dotted areas are large areas of sand dunes.

OxCal 3.10 with atmospheric data from Bronk Ramsey (2005).

An additional age for the sand layers underlying Section 8321.1 is based on Optically Stimulated Luminescence (OSL) dating (Table 1). Details on preparation and measurement techniques are described in Wintle and Murray (2006) and Preusser and others (2008). The OSL measurements were performed at the University of Bern using an automated Risoe TL/OSL-DA-20 reader with an attachment for measuring single grains.

\section{MICROPALEONTOLOGY}

Although several samples from Section 8321.1 were investigated, only samples A4 and A5 (Fig. 2) contain well-preserved and relatively abundant benthic foraminifera (Table 2; Figs. 4 and 5). These two samples, as well as several others from the same and adjacent sections contain rare to abundant gyrogonites of charophytes ascribed to the genera Chara and Lamprothamnium (Fig. 6).

\section{ForAminifERAl AsSEMBlages}

Two foraminiferal species were identified in the lowermost lacustrine deposits (samples A4 and A5): Helenina anderseni (Warren), which was dominant, and Trichohyalus aguayoi (Bermudéz) (Table 2). Both adult and juvenile growth stages were present, with adult forms strongly dominating and representing at least $84 \%$ of the species populations. Those juvenile specimens picked from the 32$\mu \mathrm{m}$ size-fraction that could not be identified at generic level accounted for $\sim 6 \%$ of the total assemblage in each sample (Table 2). In each of the adult populations of both $H$. anderseni and $T$. aguayoi, microspheric forms always outnumbered the megalospheric ones. Test abnormalities, mainly deformed chambers and aberrant chamber arrangements, were restricted to $H$. anderseni and accounted for $2-$ $6 \%$ of its populations.

\section{MORPHOLOGICAL VARIABILITY AND MORPHOMETRY OF HELENINA ANDERSENI}

In the studied material, Helenina anderseni showed a high degree of morphological variability (Fig. 4). The test outline and shape of the sutures were the most variable features, so we used them to distinguish two extreme morphotypes. Morphotype A has a subcircular profile and the sutures on its spiral side are tangential and deeply incised; sutures on the umbilical side are curved to tangential (Fig. 4.1). Morphotype A closely resembles the holotype. In contrast, morphotype B has an ovate profile and the sutures on both its spiral and umbilical sides are 


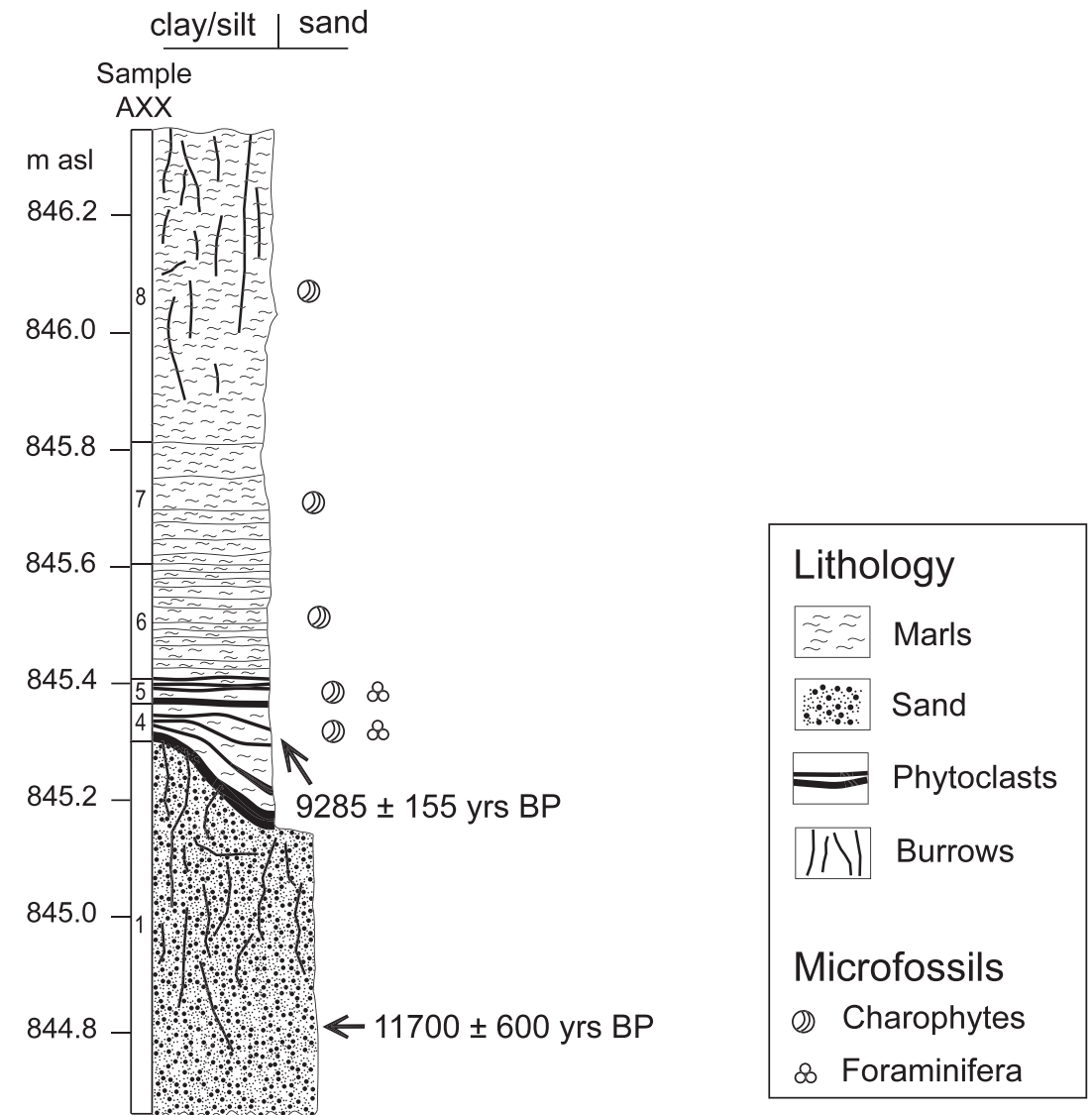

FigURE 2. Sedimentological profile of outcrop $8321.1\left(18^{\circ} 32^{\prime} 43.0^{\prime \prime} \mathrm{N}, 45^{\circ} 21^{\prime} 27.1^{\prime \prime} \mathrm{E}\right)$.

straight to slightly curved and deeply incised; its supplementary sutural apertures are generally wider than those of morphotype A (Fig. 4.4-4.6).

A morphometric study was performed to verify the characters that distinguish morphotypes $\mathrm{A}$ and $\mathrm{B}$. The morphometric parameters considered were 1) the spiral diameters ratio $(\mathrm{D} / \mathrm{B})$, which measures the degree of roundness of the test outline, 2) the Chamber Expansion Index (CEI), which indicates the increase in chamber size in the last whorl, and 3) the Dorsal Chamber View Index (DCVI), which is a measure of the degree of elongation of the penultimate chamber (see Pearson and others, 2001 for equations).

The results of the univariate and multivariate analysis (PCA) are shown in Figures 7 and 8, where they are plotted separately according to whether they have six or seven chambers in the outer whorl (Figs. 7A-C and 8A vs. Figs. 7D-F and 8B). For each group, an equal number of microspheric and megalospheric forms were measured (50 specimens each). Frequency histograms (univariate analysis) for both subsamples have a clear unimodal distribution, showing a continuous transition of the considered morphometric parameters. Results of the PCA are plotted in a PC1-PC2 graph, since the first two components account for

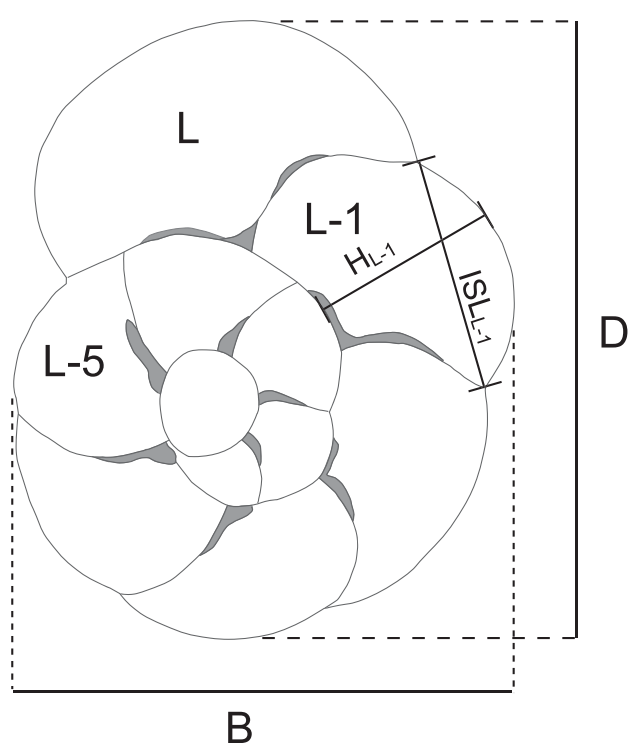

FIGURE 3. Morphometric parameters measured on the dorsal side of Helenina anderseni. Last whorl's chambers were numbered from the last one (L) backward to the first one (L-5 in this case). $\mathrm{D}=$ greatest spiral diameter; $\mathrm{B}=$ spiral diameter perpendicular to $\mathrm{D} ; \mathrm{H}=$ chamber's height; ISL $=$ inter-sutural length. 
TABLE 1. Results of AMS ${ }^{14} \mathrm{C}$ and OSL dating.

\begin{tabular}{|c|c|c|c|c|c|c|c|c|}
\hline Lab code & Outcrop & Sample & Material & Method & $\mathrm{n}$ & OD & Age (yr BP) & Calibrated age (yr BP) \\
\hline ETH-37792 & 8321.1 & A4 & Phytoclasts & ${ }^{14} \mathrm{C}$ & - & - & $8300 \pm 45$ & $9285 \pm 155$ \\
\hline ROT-77/160 & 8321.1 & A1 & Qtz grains & OSL & 24 & $9.7 \%$ & $11700 \pm 600$ & \\
\hline
\end{tabular}

$>80 \%$ of the variation (Table 3 ). The PCA plot shows a great morphometric correspondence between specimens attributed to the two identified morphotypes.

\section{Systematics And Ecology of Foraminiferal Species}

Family Heleninidae Loeblich and Tappan, 1987

Genus Helenina Saunders, 1961

Helenina anderseni (Warren)

Figures 4.1-4.6, 5.1-5.4

1957 Pseudoeponides anderseni Warren, pl. 4, figs. 12-15.

1957 Helenia anderseni (Warren), Saunders, p. 374.

1961 Helenina anderseni (Warren), Saunders, p. 136, pl. 3, fig. 3.

1996 Helenina anderseni (Warren), Culver and others, p. 480, figs. 9.10,

9.11.

1999 Helenina sp., Lipps and Langer, pl. 2, figs. 2, 5.

2003 Helenina anderseni (Warren), Javaux and Scott, p. 24, figs. 6.3, 6.4 .

2005a Helenina cf. H. anderseni (Warren), Kawagata and others, pl. 2, figs. 8-12.

2005b Helenina cf. H. anderseni (Warren), Kawagata and others, p. 224, pl. 1, figs. 5-13.

Ecology. This species has been described from estuarine environments, marshes, lagoons, and low-salinity mangrove swamps including those in North America (Culver and Horton, 2005), South America (Steinker and Butcher, 1981; Culver, 1990), the western Pacific (Lipps and Langer, 1999; Kawagata and others, 2005a, 2005b), New Zealand (Gregory, 1973; Hayward and Hollis, 1994; Hayward and others, 1999), New Caledonia and Australia (Debenay and Guillou, 2002), the Red Sea (Halicz and others, 1984), and the Venice lagoon (Serandrei Barbero and others, 2004). Very rarely has it been found in hypersaline lagoons

TABLE 2. Relative abundance $(\%)$ of Helenina anderseni and Trichohyalus aguayoi in total assemblage. For each species, the relative abundance of adults (microspheric and megalospheric forms), juveniles, and abnormal specimens are also indicated. *Juveniles (in 32$\mu \mathrm{m}$ fraction) not identified at generic level.

\begin{tabular}{lcc}
\hline \multicolumn{1}{c}{ Sample } & A4 & A5 \\
\hline Weight dry sediment (g) & 40 & 30 \\
Total number of counted specimens & 3227 & 2354 \\
Species & Relative abundance (\%) \\
Helenina anderseni in total assemblage & $\mathbf{9 3 . 5}$ & $\mathbf{8 7 . 9}$ \\
adults & 95.0 & 94.0 \\
$\quad$ microspheric forms & 62.0 & 59.2 \\
$\quad$ megalospheric forms & 38.0 & 40.8 \\
juveniles & 5.0 & 6.0 \\
abnormal specimens & 1.9 & 6.1 \\
Trichohyalus aguayoi in total assemblage & $\mathbf{0 . 7}$ & $\mathbf{5 . 9}$ \\
adults & 95.5 & 84.2 \\
$\quad$ microspheric forms & 52.4 & 60.7 \\
megalospheric forms & 47.6 & 39.3 \\
juveniles & 4.5 & 15.8 \\
abnormal specimens & - & - \\
Indet. juveniles* in total assemblage & 5.8 & 6.2 \\
\hline
\end{tabular}

(Debenay and others, 2001). It is purportedly an infaunal species (Culver and Horton, 2005).

Family Trichohyalidae Saidova, 1981

Genus Trichohyalus Loeblich and Tappan, 1953

Trichohyalus aguayoi (Bermúdez)

Figures 5.5-5.7

1935 Discorbis aguayoi Bermúdez, pl. 15, figs. 10-14.

1950 Discorbina lacunae Silvestri, pl. 3, figs. 9, 10.

1991 Trichohyalus lacunae (Silvestri), Albani and others, pl. 1, figs. 9, 10.

2004 Discorinopsis aguayoi (Bermúdez), Foresi and others, pl. 2, figs.

1-11, pl. 3, figs. 1-12, pl. 4, figs. 1-13.

Remarks. We retain the assignment of this genus to Trichohyalus because of its truly calcareous wall texture as opposed to Discorinopsis, which is agglutinated with calcareous particles. Foresi and others (2004) placed $T$. lacunae in synonymy with $T$. aguayoi because they concluded that chamber shape is highly variable in this species. Features that they considered as invariant characteristics determined by genetic characters include the numerous chambers in the last whorl, primary and secondary apertures, coarse pores, limbation of the sutures, depressed sutures in the last whorl, and test contortion. Although taxonomy is beyond the scope of this paper, we note that $T$. aguayoi was present in our material as two quite distinct forms that differ in chamber shape in umbilical view. One is T. aguayoi sensu stricto (Fig. 5.5) with slightly curved sutures, while the other has the $T$. lacunae morphology (Figs. 5.6, 5.7) with sigmoid sutures resulting from the overlapping of chambers in the last whorl.

Ecology. This species can tolerate a wide range of salinities. Most often, it has been reported in fresh to brackish waters (Wantland, 1975; Javaux and Scott, 2003) and mangrove swamps (Steinker and Butcher, 1981; Javaux and Scott, 2003). It has also been recorded in the Montecatini thermal pool and Orbetello lagoon (Zampi and others, 1996; Foresi and others, 2004). Occurrences in hypersaline lagoons are rare (Debenay and others, 2001).

\section{DISCUSSION}

\section{PALEOENVIRONMENTAL INTERPRETATION}

Regional climate records (McClure, 1976; Lezine and others, 1998; Burns and others, 2001; Preusser and others, 2002; Radies and others, 2005; Fleitmann and others, 2007) indicate an early Holocene wet phase in southern Arabia. In particular, speleothems from Oman provide a record of pluvial intervals beween 10,500-6,000 yr BP (Fleitmann and others, 2003a, 2003b, 2007). The radiocarbon age of $9285 \pm 155$ cal. yr BP we obtained from sample A4 phytoclasts falls within this interval (Table 1). As a result of increased monsoon precipitation at that time, the $\mathrm{Al}$ 


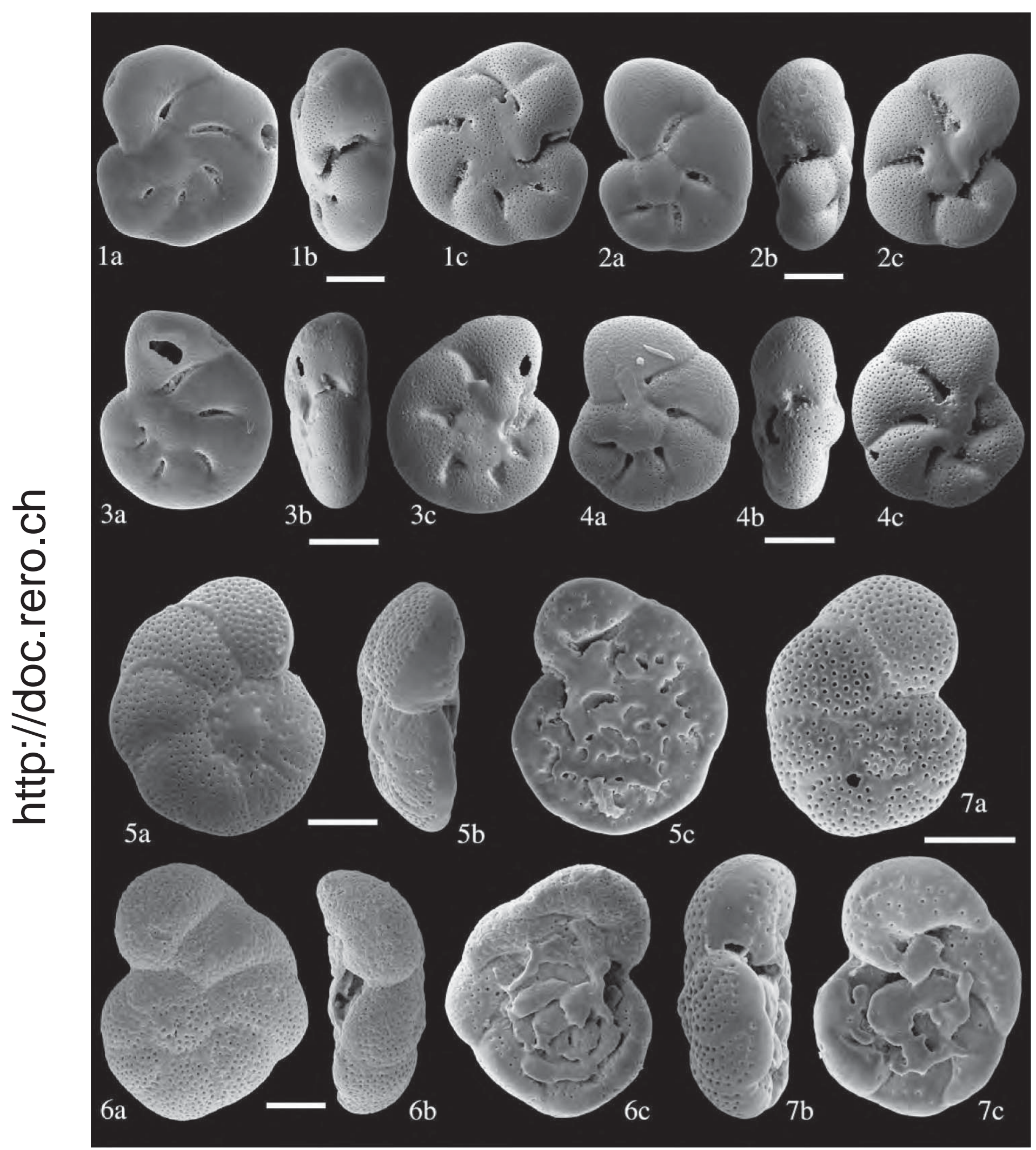

FIGURE 5. 1-4 Helenina anderseni, juvenile specimens: a, spiral view; b, side view; c, umbilical view. 5 Trichohyalus aguayoi (sensu stricto): a, spiral view; b, side view; c, umbilical view. 6, 7 T. aguayoi (T. lacunae-type): a, spiral view; b, side view; c, umbilical view. Scale bars $1-4=50 \mu \mathrm{m}, 5-7=$ $100 \mu \mathrm{m}$. 

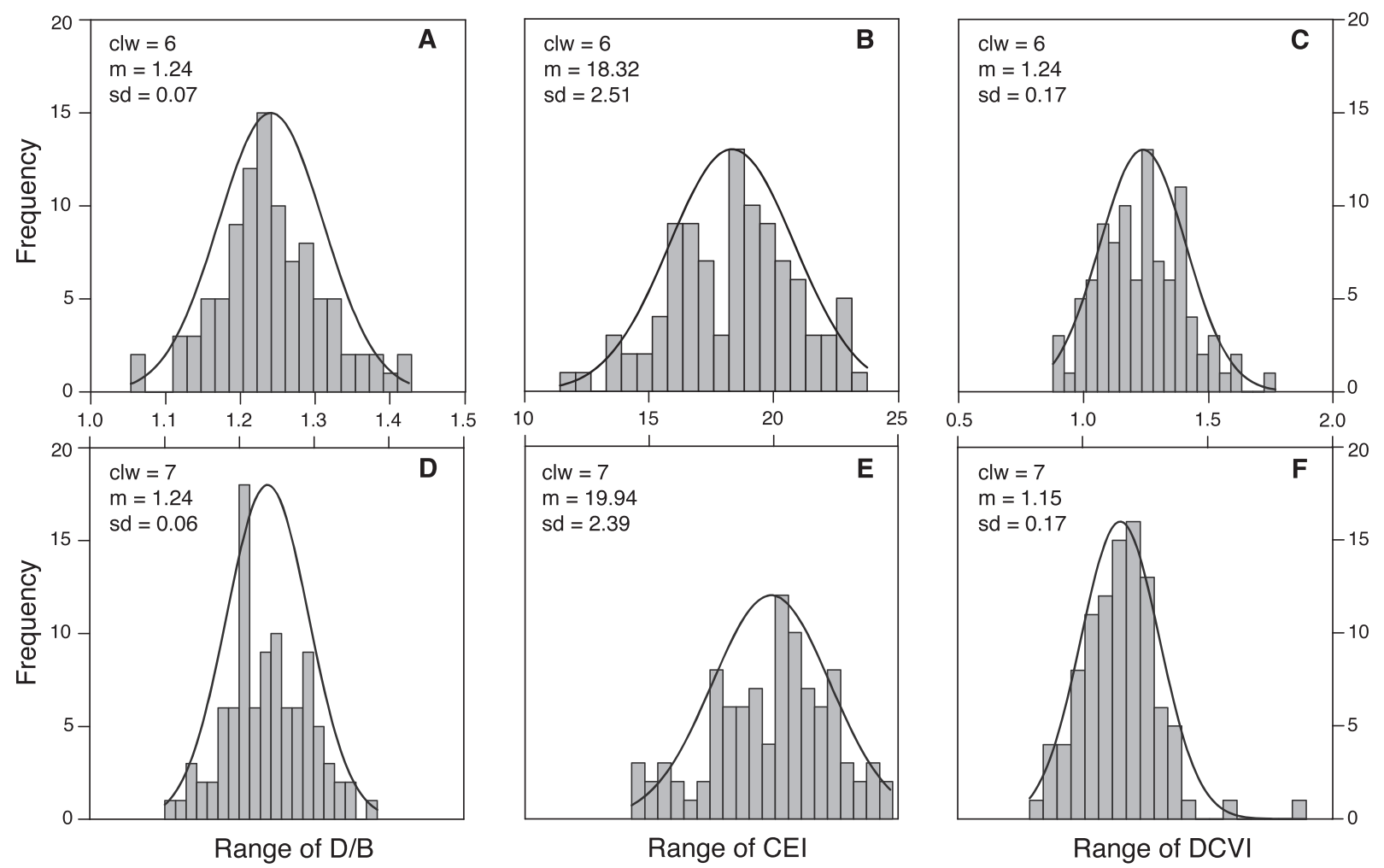

FIGURE 7. Morphometric data measured on Helenina anderseni plotted as standard histograms (frequency). Normal Curve Shape is shown as a solid line. D/B = spiral diameters ratio; CEI = Chamber Expansion Index; DCVI = Dorsal Chamber View Index; clw = number of chambers in last whorl; $\mathrm{m}=$ mean; $\mathrm{sd}=$ standard deviation (Pearson and others, 2001).

Tolypella), determined at the specific level on the basis of the morphology of both vegetative parts and reproductive organs (gyrogonites). Since only gyrogonites have been preserved, their taxonomic attributions, and consequently their ecological value, are restricted. There are $\sim 400$ charophyte species in modern flora, six strictly brackish, ten species brackish to freshwater, and the rest freshwater (Corillion, 1972). Thus, fossil charophytes are typically assumed to be freshwater indicators. The charophyte assemblage of $\mathrm{Al}$ Mundafan is represented mostly by forms very similar to Chara globularis var. aspera (Figs. 6.6-6.8) with very elongated morphotypes characteristic of slightly brackish environments (salinity $\sim 2 \%$; Soulie-Märsche, 1989). Levels A7, A8, and possibly A6 yielded rare specimens ascribed to Lamprothamnium (Figs. 6.1-6.5), which is one of the most typical brackish genera (Corillion, 1972). Large amounts of fragile gyrogonites are strong indication that these fossil floras are in situ. This implies that deposition occurred in water depths shallower than six meters, which is the limit for charophytes to fructify (Becker and others, 2002; Picot, 2003).

\section{Transportation Mechanism and Provenance of BENTHIC FORAMINIFERA}

The presence of benthic foraminifera in inland saline or brackish waters is rare, but cannot be considered unusual (Resig, 1974). Most of their fossil record has probably been erased primarily because they have thin shells that are susceptible to dissolution (e.g., Jonasson and Patterson, 1992; Culver and Horton, 2005).

As reported by Resig (1974), three hypotheses have been proposed to explain the occurrence of these forms in inland waters that were never connected to the sea: endemism (Daday, 1884), marine reliction (Brodsky, 1928; GauthierLièvre, 1935), and transport via avian or human means (Arnal, 1954; Almogi-Labin and others, 1992; Patterson and others, 1997).

Species diversity in comparable environments varies considerably. In the Hawaiian Salt Lake, Resig (1974) recorded 41 species, including calcareous and agglutinated forms. In stark contrast, Almogi-Labin and others (1992) reported monospecific assemblages of Ammonia tepida in the Dead Sea, and Wennrich and others (2007) found only two species in two inland brackish lakes (Salziger See and Suesser See) in central Germany. Moderate numbers of species were documented by Abu-Zied and others (2007), with 15 calcareous species from Lake Qarun (Egypt). In the meromictic Mecherchar Jellyfish Lake in Palau, Lipps and Langer (1999) identified 15 species (agglutinated and calcareous) in surface sediments, while Kawagata and others (2005b) observed ten calcareous species in a sediment core retrieved from the same lake, with only two species (Helenina $\mathrm{cf}$. H. anderseni and Bolivina striatula) common to the two studies. All of these studies discussed the provenance of their benthic foraminiferal assemblages from nearby or relatively far marine coastal environments when there were temporary connections with the sea or dry 

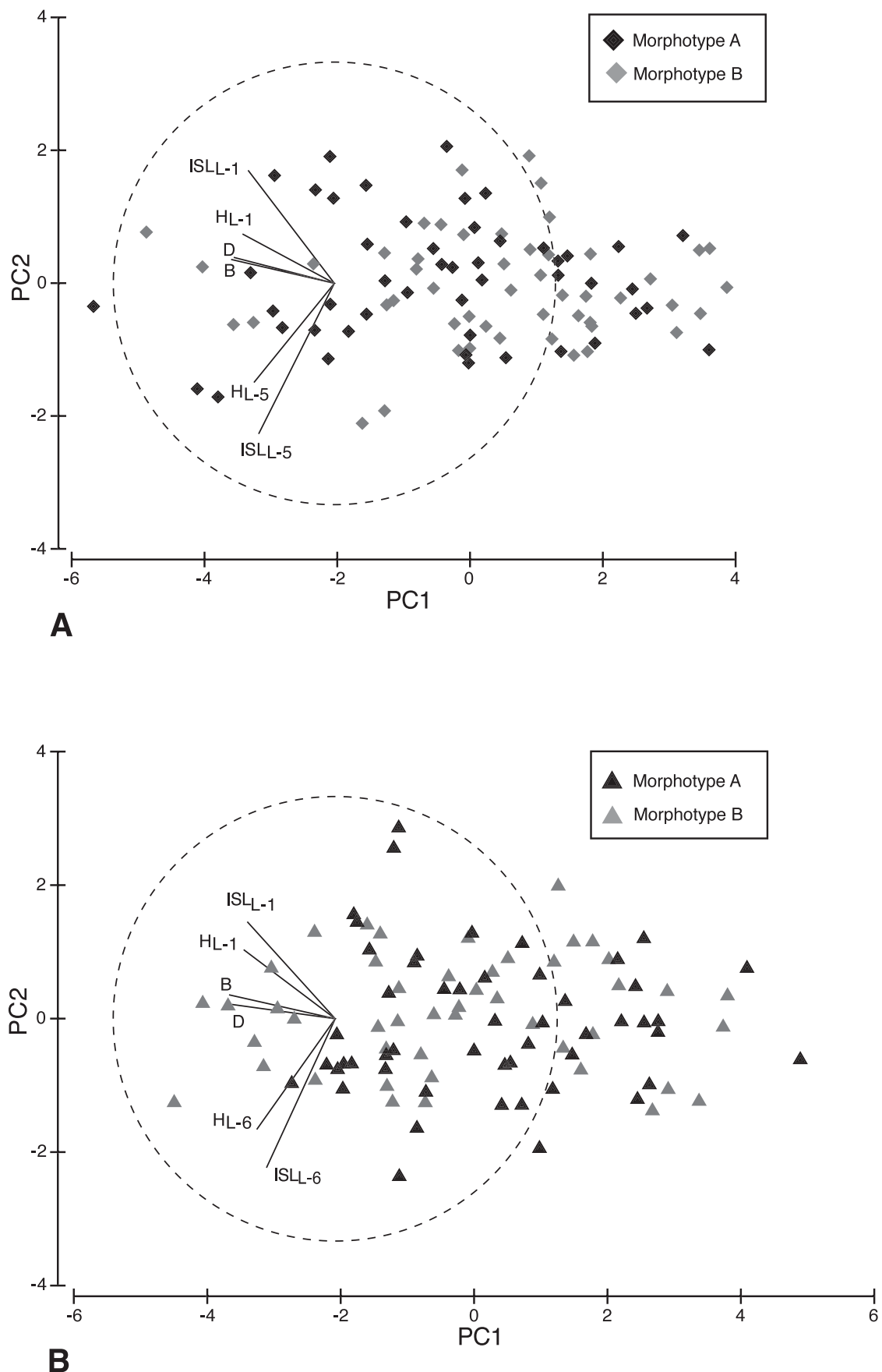

FIGURE 8. Principal component analysis applied to morphometric measurements of Helenina anderseni. $\mathrm{A}=$ specimens with six chambers in the last whorl; $\mathrm{B}=$ specimens with seven chambers in the last whorl. $\mathrm{D}=$ greatest spiral diameter; $\mathrm{B}=$ spiral diameter perpendicular to $\mathrm{D} ; \mathrm{H}=$ chamber's height; ISL $=$ inter-sutural length.

intervals characterized by increasing salinity. In our materials, benthic foraminifera are represented by two genera (Helenina and Trichohyalus) characteristic of mangrove swamps, salt marshes, and lagoons (e.g., Tufesco, 1969; Javaux and Scott, 2003; Culver and Horton, 2005). To explain the presence of benthic foraminifera in the Mundafan region, we can exclude endemism and marine reliction, as it was never connected to the sea during the Quaternary. The most likely explanation for their occurrence in the Mundafan paleolake is avian-mediation, which
Patterson and others (1997) suggested being a much more important foraminiferal dispersal mechanism than usually realized. Although there is extensive literature on the mangrove swamps, salt marshes, and lagoons flanking the Red Sea (e.g., Mohamed, 1984; Saleh, 2007), little is known about their foraminifera. Because these transitional environments are suitable habitats for $H$. anderseni and $T$. aguayoi, it is reasonable to assume that those along the Egyptian-Sudanese and Saudi Arabian coasts of the Red Sea most likely are the provenance of the $H$. anderseni and 
TABLE 3. Principal components analysis: eigenvalues and eigenvectors (coefficients in the linear combinations of variables making up the principal components) for the six analyzed variables. *Normalized before PCA analysis.

\begin{tabular}{|c|c|c|c|c|c|c|c|c|c|c|c|}
\hline \multirow[b]{2}{*}{ No. ch. } & \multicolumn{4}{|c|}{ Eigenvalues } & \multicolumn{7}{|c|}{ Eigenvectors } \\
\hline & $\mathrm{PC}$ & $\begin{array}{l}\text { Eigen- } \\
\text { values }\end{array}$ & $\begin{array}{c}\% \\
\text { Variation }\end{array}$ & $\begin{array}{l}\text { Cum. \% } \\
\text { Variation }\end{array}$ & Variable & $\mathrm{PC} 1$ & $\mathrm{PC} 2$ & $\mathrm{PC} 3$ & $\mathrm{PC} 4$ & PC5 & PC6 \\
\hline & 2 & 0.756 & 12.6 & 82.0 & B & -0.467 & 0.108 & -0.039 & -0.105 & 0.274 & -0.826 \\
\hline & 3 & 0.504 & 8.4 & 90.4 & $\mathrm{H}_{\mathrm{L}-1}$ & -0.416 & 0.223 & -0.473 & -0.541 & -0.470 & 0.199 \\
\hline & 4 & 0.284 & 4.7 & 95.2 & ISL $_{\mathrm{L}-1}$ & -0.390 & 0.511 & 0.250 & 0.627 & -0.353 & 0.079 \\
\hline & 5 & 0.198 & 3.3 & 98.4 & $\mathrm{H}_{\mathrm{L}-5}$ & -0.364 & -0.448 & 0.718 & -0.294 & -0.244 & 0.070 \\
\hline \multirow[t]{6}{*}{7} & 1 & 3.93 & 65.5 & 65.5 & D & -0.473 & 0.065 & -0.028 & 0.013 & -0.576 & -0.663 \\
\hline & 2 & 0.922 & 15.4 & 80.8 & $\mathrm{~B}$ & -0.478 & 0.108 & -0.046 & 0.022 & -0.450 & 0.745 \\
\hline & 3 & 0.478 & 8.0 & 88.8 & $\mathrm{H}_{\mathrm{L}-1}$ & -0.412 & 0.311 & 0.255 & 0.690 & 0.436 & -0.051 \\
\hline & 4 & 0.335 & 5.6 & 94.4 & ISL $_{\mathrm{L}-1}$ & -0.396 & 0.437 & -0.022 & -0.691 & 0.415 & -0.047 \\
\hline & 5 & 0.275 & 4.6 & 99.0 & $\mathrm{H}_{\mathrm{L}-6}$ & -0.353 & -0.498 & -0.728 & 0.092 & 0.297 & -0.023 \\
\hline & 6 & $6.07 \mathrm{E}-2$ & 1.0 & 100 & ISL $_{\mathrm{L}-6}$ & -0.310 & -0.670 & 0.634 & -0.194 & 0.123 & 0.017 \\
\hline
\end{tabular}

T. aguayoi specimens that pioneered the Mundafan paleolake. The absence of other taxa in the paleolake may relate to the low diversity of the foraminiferal faunas in mangrove swamps (e.g., Culver, 1990). Therefore, we postulate that avian-mediated transport from the margins of the Red Sea introduced the two foraminiferal species that colonized the Mundafan brackish paleolake.

\section{CONCLUSIONS}

The presence of two benthic foraminiferal species, Helenina anderseni and Trichohyalus aguayoi and charophytes in lacustrine sediments of the Al Mundafan section are linked to the continental pluvial periods that occurred in the area 10,500-6,000 $\mathrm{yr}$ BP (Fleitmann and others, 2003a, 2003b, 2007). Enhanced precipitation created a freshwater lake with temporarily brackish conditions. This is corroborated by the presence of reproducing populations of foraminifera and in situ brackish charophytes. Because the Al Mundafan paleo-lake was never connected to the sea, the foraminifera were most likely introduced by avianmediated transport from mangrove swamps along the coasts of the Red Sea.

\section{ACKNOWLEDGMENTS}

We warmly thank Irka Hajdas, ETH Zurich, for AMS radiocarbon dating. We also thank John Murray and an anonymous reviewer for their useful revision of the manuscript. Kenneth Finger is kindly acknowledged for editing the manuscript. This research was funded by the Swiss National Foundation Projects 200021-117985, 206021-117374 and 200021-111694 and by the Saudi Geological Survey.

Author contributions: GG and SS carried out the foraminiferal study and wrote the paper; TR did the fieldwork, described and sampled the section, performed the OSL dating and contributed to writing; J-PB. studied the charophytes, AM initiated the project, organized and supervised the fieldwork; DF and FP supervised the project and contributed to the discussion, and MA-S was responsible for the field logistics.

\section{REFERENCES}

Abu-Zied, R. H., Keatings, K. W., and Flower, R. J., 2007, Environmental controls on foraminifera in Lake Qarun, Egypt: Journal of Foraminiferal Research, v. 37, p. 136-149.

Albani, A., Favero, V. M., and Serandrei Barbero, R., 1991, The distribution and ecological significance of Recent foraminifera in the lagoon south of Venice (Italy): Revista Española de Micropaleontología, v. 23, p. 29-45.

Almogi-labin, A., Perelis-Grossovicz, L., and RaAB, M., 1992, Living Ammonia from a hypersaline inland pool, Dead Sea area, Israel: Journal of Foraminiferal Research, v. 22, p. 257-266.

Alve, E., 1991, Benthic foraminifera in sediment cores reflecting heavy metal pollution in Sørfjord, western Norway: Journal of Foraminiferal Research, v. 21, p. 1-19.

, and Goldstein, S. T., 2003, Propagule transport as a key method of dispersal in benthic foraminifera (Protista): Limnology and Oceanography, v. 48, p. 2163-2170.

Arnal, R. E., 1954, Preliminary report on the sediments and foraminifera of the Salton Sea, southern California: Geological Society of America Bulletin, v. 65, p. 1227-1228.

Becker, D., Picot, L., and Berger, J.-P., 2002, Stable isotopes $\left(\delta^{13} \mathrm{C}\right.$ and $\delta^{18} \mathrm{O}$ ) of charophytes gyrogonites: example form the Brochnene Fluh section (late Oligocene-early Miocene, Switzerland): Geobios, v. 35, p. 89-97.

BermúdeZ, P. J., 1935, Foraminiferos de la costa norte de Cuba: Memorias de la Sociedad Cubana de Historia Natural, v. 9, p. 129-224.

Boltovskoy, E., and Wright, R., 1976, Recent Foraminifera: W. Junk, The Hague, 515 p.

Brodsky, A. A., 1928, Foraminifera (Polythalamia) in the wells of the Kara-Kum desert: Trudy Sredne-Aziatskogo Gosudarstvennogo Universiteta; Serija 8a, Zoologija, v. 8, p. 6-36. (In Russian).

BRONK RAMSEY, C., 2005, Improving the resolution of radiocarbon dating by statistical analysis, in Levy, E. E., and Higham, T. F. G. (eds.), The Bible and radiocarbon dating: Archeology, Text and Science: Equinox, London, p. 57-64.

Burns, S. J., Fleitmann, D., Matter, A., Neff, U., and Mangini, A., 2001, Speleothem evidence from Oman for continental pluvial events during interglacial periods: Geology, v. 29, p. 623-626.

Clarke, K. R., and Gorley, R. N., 2006, PRIMER v6: user Manual/ Tutorial: PRIMER-E, Plymouth, 190 p.

, and WARWICK, R. M., 2001, Change in marine communities: an approach to statistical analysis and interpretation, $2^{\text {nd }}$ Edition: PRIMER-E, Plymouth, 172 p.

Corillion, R., 1972, Les Charophycées de France et de l'Europe Occidentale: Otto Koeltz Verlag, Kooenigstein, 499 p.

Culver, S. J., 1990, Benthic foraminifera of Puerto Rican mangrovelagoon systems: potential for paleoenvironmental interpretations: Palaios, v. 5, p. 34-51.

, and Horton, B. P., 2005, Infaunal marsh foraminifera from the Outer Banks, North Carolina, U.S.A.: Journal of Foraminiferal Research, v. 35, p. 148-170. 
, Jun Woo, H., Oertel, G. F., and Buzas, M. A., 1996, Foraminifera of coastal depositional environments, Virginia, U.S.A.: distribution and taphonomy: Palaios, v. 11, p. 459-486.

DADAY, E. V., 1884, Über eine Polythalamie der Kochsalztümpel bei Deva in Siebenbürgen: Zeitschrift für Wissenschaftliche Zoologie, v. 40 , p. $465-480$.

Debenay, J.-P., and Guillou, J.-J., 2002, Ecological transitions indicated by foraminiferal assemblages in paralic environments: Estuaries, v. 25, p. 1107-1120.

- - Geslin, E., Beck Eichler, B., Duleba, W., Sylvestre, F., and EICHLER, P., 2001, Foraminiferal assemblages in an hypersaline lagoon, Araruma (R.J.), Brazil: Journal of Foraminiferal Research, v. 31, p. 133-151

Fleitmann, D., Burns, S. J., NefF, U., Mangini, A., and Matter, A., 2003a, Changing moisture sources over the last 330,000 years in northern Oman from fluid inclusion evidence in speleothems: Quaternary Research, v. 60, p. 223-232.

, Mudelsee, M., NefF, U., Kramers, J., Mangini, A., and Matter, A., 2003b, Holocene forcing of the Indian monsoon recorded in a stalagmite from southern Oman: Science, v. 300, p. $1737-1739$.

- Mangini, A., Mudelsee, M., Kramers, J., Villa, I., Neff, U., Al-Subbary, A. A., Buettner, A., Hippler, D., and MAtTer, A., 2007, Holocene ITCZ and Indian monsoon dynamics recorded in stalagmites from Oman and Yemen (Socotra): Quaternary Science Reviews, v. 26, p. 170-188.

Foresi, L. M., ZAMPI, M., and FocArdi, S., 2004, Test morphology and organic layer of Discorinopsis aguayoi (Bermudéz): relationships with environmental conditions: Revista Española de Micropaleontología, v. 36, p. 323-347.

GAuthiER-Lièvre, L., 1935, Sur une des singularités de l'Oued Rhir: Des foraminifères thalassoïdes vivant dans des eaux sahariennes: Bulletin de la Société d'Histoire Naturelle de l'Afrique du Nord, v. 26 , p. 142-147.

Geslin, E., Debenay, J.-P., Duleba, W., and Bonetti, C., 2002, Morphological abnormalities of foraminiferal tests in Brazilian environments: comparison between polluted and non-polluted areas: Marine Micropaleontology, v. 45, p. 151-168.

Gregory, M. R., 1973, Benthonic foraminifera from a mangrove swamp, Whhangaparapara, Great Barrier Island: Tane, v. 19, p. 193-204.

Halicz, E., Noy, N., and Reiss, Z., 1984, Foraminifera from Shura Arwashie mangrove (Sinai), in Por, F. D., and Dor, I. (eds.), Hydrobiology of the Mangal: Dr. W. Junk b.v., The Hague, p. $145-149$.

HALlock, P., 1985, Why are larger foraminifera large?: Paleobiology, V. 11, p. 195-208.

Hayward, B. W., and Hollis, C. J., 1994, Brackish foraminifera in New Zealand: a taxonomic and ecologic review: Micropaleontology, v. 40, p. 185-222.

, Grenfell, H. R., and ScotT, D. B., 1999, Tidal range of marsh foraminifera for determining former sea-level heights in New Zealand: New Zealand Journal of Geology \& Geophysics, v. 42 , p. $395-413$.

JAVAuX, E. J., and ScotT, D. B., 2003, Illustration of modern benthic foraminifera from Bermuda and remarks on distribution in other tropical/subtropical areas: Palaeontologia Electronica, v. 6, p. 29. 2.1MB, http://palaeo-electronica.org/paleo/20031/benthic/issue1 03.htm.

Jonasson, K. E., and Patterson, R. T., 1992, Preservation potential of salt marsh foraminifera from the Fraser River delta, British Columbia: Micropaleontology, v. 38, p. 289-301.

Kawagata, S., Yamasaki, M., and Jordan, R. W., 2005a, Acarotrochus lobulatus, a new genus and species of shallow-water benthic foraminifera from Mecherchar Jellyfish Lake, Palau, NW Equatorial Pacific Ocean: Journal of Foraminiferal Research, v. 35 , p. $44-49$.

, Genka, R., and Jordan, R. W., 2005b, Shallow-water benthic foraminifers from Mecherchar Jellyfish Lake (Ongerul Tketau Uet), Palau: Micronesica, v. 37, p. 215-233.

Lévy, A., Mathieu, R., Poignant, A., and Fernandez-Gonzalez, M., 1995, Sur la signification des foraminifères dans les dépôts continentaux: Oceanologica Acta, v. 18, p. 597-605.
Lézine, A. M., Saliège, J. F., Robert, C., Wertz, F., and Inizan, M. L., 1998, Holocene lakes from Ramlat as-Sab'atayn (Yemen) illustrate the impact of monsoon activity in southern Arabia: Quaternary Research, v. 50, p. 290-299.

LIPPS, J. H., and LANGER, M. R., 1999, Benthic foraminifera from the meromictic Mecherchar Jellyfish Lake, Palau (western Pacific): Micropaleontology, v. 45, p. 278-284.

Loeblich, A. R., JR., and TAppan, H., 1953, Studies of Arctic foraminifera: Smithsonian Miscellaneous Collections, v. 121, (7), p. $1-150$.

, and , 1987, Foraminiferal Genera and Their Classification: Van Nostrand Reinhold Company, New York, 2 vol., $1182 \mathrm{p}$.

MCClure, H. A., 1976, Radiocarbon chronology of late Quaternary lakes in Arabian deserts: Nature, v. 263, p. 755-756.

, and SwaIn, F. M., 1980, Fresh-water and brackish-water fossil Quaternary Ostracoda from the Rub' al Khali ('Empty Quater'), Saudi Arabia: Actes du VI ${ }^{\mathrm{e}}$ Colloque Africain de Micropaléontologie - Tunis 1974, Annales des Mines et de la Géologie, v. 28, p. $427-441$.

Mohamed, B. F., 1984, Ecological observations on the mangroves of the Red Sea shores of Sudan: Hydrobiologia, v. 110, p. 109-111.

Patterson, R. T., Scott, D. B., and McKillop, W. B., 1990, Recent marsh-type agglutinated foraminifera in Lake Winnipegosis, Manitoba, in Hemleben, C., Kaminski, M. A., Kuhnt, W., and Scott, D. B. (eds.), Paleoecology, Biostratigraphy, Paleoceanography and Taxonomy of Agglutinated Foraminifera. Nato Science Series C, 327: Kluwer Academic Publisher, Dordrecht, p. 765781.

, McKillop, W. B., Kroker, S., Nielsen, E., and Reinhardt, E. G., 1997, Evidence of rapid avian-mediated foraminiferal colonization of Lake Winnipegosis, Manitoba, during the Holocene Hypsithermal: Journal of Paleolimnology, v. 18, p. 131-143.

Pearson, P. N., Norris, R. D., and Empson, A. J., 2001, Mutabella mirabilis gen. et sp. nov., a Miocene microperforate planktonic foraminifera with an extreme level of intraspecific variability: Journal of Foraminiferal Research, v. 31, p. 120-132.

Picot, L., 2003, Le Paléogène des synclinaux du Jura et de la bordure sud-rhénane: paléontologie (ostracodes), paléoécologie, biostratigraphie et paléogéographie, Geofocus, v. 5, p. 240.

Preusser, F., Radies, D., and Matter, A., 2002, A 160,000-year record of dune development and atmospheric circulation in southern Arabia: Science, v. 296, p. 2018-2020.

, Degering, D., Fuchs, M., Hilgers, A., Kadereit, A., Klasen, N., KrbetscheK, M., Richter, D., and Spencer, J., 2008, Luminescence dating: basics, methods and applications: Eiszeitalter \& Gegenwart (Quaternary Science Journal), v. 57, p. $95-149$.

Radies, D., Hasiotis, S. T., Preusser, F., Neubert, E., and Matter, A., 2005, Paleoclimatic significance of early Holocene faunal assemblages in wet interdune deposits of the Wahiba Sand Sea, Sultanate of Oman: Journal of Arid Environments, v. 62, p. 109-125.

Resig, J. M., 1974, Recent foraminifera from a landlocked Hawaiian lake: Journal of Foraminiferal Research, v. 4, p. 69-76.

SAIDOVA, K. M., 1981, On an up-to-date system of supraspecific taxonomy of Cenozoic benthonic foraminifera: Institut Okeanologi P. P. Shirshova, Akademiya Nauk SSSR, Moscow, 73 p. (In Russian).

SAleh, M. A., 2007, Assessment of mangrove vegetation on Abu Minqar Island of the Red Sea: Journal of Arid Environments, v. 68 , p. $331-336$.

SAunders, J. B., 1957, Emendation of the foraminiferal genus Palmerinella Bermudez, 1934, and erection of the foraminiferal genus Helenia: Journal of the Washington Academy of Sciences, v. 47, p. 374.

, 1961, Helenina Saunders, new name for the foraminiferal genus Helenia Saunders, 1957, non Helenia Walcott, 1880: Contributions from the Cushman Foundation for Foraminiferal Research, v. 12, p. 128.

Serandrei Barbero, R., Albani, A. D., and Bonardi, M., 2004, Ancient and modern salt marshes in the lagoon of Venice: 
Palaeogeography, Palaeoclimaltology, Palaeoecology, v. 202, p. 229-244.

Silvestri, A., 1950, Foraminiferi della Laguna Veneta: Bollettino Pesca, Piscicultura e Idrobiologia, v. 5, p. 22-98.

Soulie-Märsche, I., 1989, Etude Comparée de Gyrogonites de Charophytes Actuelles et Fossiles et Phylogénie des Genres Actuels: Imprimerie des Tilleuls, Millau, France, $237 \mathrm{p}$.

Steinker, D. C., and Butcher, W. A., 1981, Foraminifera from mangrove shores, Bermuda: Micron, v. 12, p. 223-224

Tufesco, M., 1969, Sur la présence de Trichohyalus aguayoi (Bermudez) dans la Mer Noire: Revue de Micropaléontologie, v. 12, p. $46-52$.

Wantland, K. F., 1975, Distribution of Holocene benthonic foraminifera on the Belize Shelf, in Wantland, K. F., and Pursey, W. C., III (eds.), Belize Shelf - Carbonate Sediments, Clastic Sediments and Ecology: American Association of Petroleum Geologists Studies in Geology, v. 2, p. 332-399.
Warren, A. D., 1957, Foraminifera of the Buras-Scofield Bayou region, southeast Lousiana: Contributions of the Cushman Foundation for Foraminiferal Research, v. 8, p. 29-40.

Wennrich, V., Meng, S., and Schmiedl, G., 2007, Foraminifers from Holocene sediments of two inland brackish lakes in central Germany: Journal of Foraminiferal Research, v. 37, p. 318-326.

WinTLE, A. G., and MurRaY, A. S., 2006, A review of quartz optically stimulated luminescence characteristics and their relevance in single-aliquot regeneration dating protocols: Radiation Measurements, v. 41, p. 369-391.

ZAmPI, M., Foresi, L. M., and Benocci, S., 1996, Nuove osservazioni su morfologia ed ecologia di Miliammina fusca (Brady) e Discorinopsis aguayoi (Bermudez) rinvenuti in una vasca termale in Montecatini Terme (Pistoia): Atti della Società Toscana di Scienze Naturali, Serie A, v. 103, p. 17-25.

\section{APPENDIX 1}

Taxonomic notes on Helenina anderseni (Warren).

Helenina anderseni, morphotype A. The test of this type is calcareous, finely perforate, and generally small to very small in size. The trochospire is low and consists of about two whorls. Six to eight chambers gradually increasing in size as added are present in the last whorl. On the umbilical side successive chambers extend toward the umbilicus producing umbilical flaps that conceal the umbilicus. The profile is subcircular and the peripheral margin is rounded. The sutures on the spiral side are tangential and deeply incised. On the umbilical side, sutures are curved to tangential. Elongated and slit-like supplementary apertures are present along the sutures on both sides. The primary aperture is a very umbilical-extraumbilical low arch at the base of the last chamber. The two small openings at the base of the apertural face as described in Warren (1957) are probably the opening along the insertion of the lobe like extension of the last chamber on the umbilical side.

Helenina anderseni, morphotype B. The test of this type is calcareous, finely to moderately coarsely perforate, small to very small in size. The trochospire is low and consists of two whorls. Six to eight chambers are present in the last whorl and increase rapidly in size as added. The profile is oval and the peripheral margin is rounded. The sutures on the spiral and umbilical sides are straight to slightly curved and deeply incised. Elongated and wide supplementary apertures are present along the sutures on both sides. The primary aperture is a very umbilical-extraumbilical low arch at the base of the last chamber. A flap-like prolongation of the chambers in the last whorl extends on the umbilical side and conceals the umbilicus.

\section{APPENDIX 2}

Morphometric measurements of Helenina anderseni.

This table can be found on the Cushman Foundation website in the JFR Article Data Repository (http//www.cushmanfoundation.org/jfr/index/ html) as item number JFR/DR201107. 